Research Article

\title{
Study of oral hygienic practices and oral health status among school children in Jabalpur, Madhya Pradesh: a cross-sectional study
}

\author{
Shashi Prabha Tomar ${ }^{1}$, Pradeep Kumar Kasar $^{2}$, Rajesh Tiwari ${ }^{3}$
}

\begin{abstract}
${ }^{1}$ Assistant Professor, ${ }^{2}$ Professor and Head, ${ }^{3}$ Associate professor, Department of Community Medicine, NSCBMC, Jabalpur, MP, India
\end{abstract}

Received: 24 December 2015

Accepted: 06 January 2016

\section{*Correspondence:}

Dr. Shashi Prabha Tomar,

E-mail: tomarshashi9@gmail.com

Copyright: ( $\odot$ the author(s), publisher and licensee Medip Academy. This is an open-access article distributed under the terms of the Creative Commons Attribution Non-Commercial License, which permits unrestricted non-commercial use, distribution, and reproduction in any medium, provided the original work is properly cited.

\section{ABSTRACT}

Background: Oral hygiene should be educated and practiced at early age as it is one of the determinants of the health state later in one's life. Considering the fact that there is the rise in the number of dental problems in school going children, the present study was undertaken to find out the oral hygienic practices among school going children and assess their oral health status.

Methods: A cross sectional study carried out in 150 school children from two schools near medical area Jabalpur (75 from each school)between the age group of $10-15$ years. A p-value of $<0.05$ was considered statistically significant for applied statistical tests.

Results: The present study showed that only $34 \%$ children had habit of brushing both time morning and at night before going to bed. Only $22 \%$ of children used correct brushing technique. Most common malpractice among children was eating chalk $12 \%$. Regarding oral health status of school children dental caries $54.7 \%$ followed by dental cavities $(52.7 \%)$ were most common problems found.

Conclusions: Oral hygienic practices were poor needs educational motivation regarding duration of brushing, appropriate way to brush the teeth, and use of mouthwash.

Keywords: Dental caries, Oral health, Oral hygiene

\section{INTRODUCTION}

Oral health is important for appearance, sense of wellbeing and also for overall health and oral health can affect quality of life directly and has been linked to sleeping problems, as well as behavioural and developmental problems in children. ${ }^{1,2}$ Hygienic oral health practices are necessary from a young age to ensure positive long term dental health and hygiene. ${ }^{3}$ Oral health may be defined as a standard of health of the oral and related tissues which enables an individual to eat, speak and socialize without active disease, discomfort or embarrassment and which contributes to general wellbeing and the oral health of children is important towards their overall wellbeing. ${ }^{4,5}$ Dental carries and periodontal problems are due to poor oral hygiene practices. ${ }^{1-3}$

Oral health is an integral part of general health; therefore, its disregarding will give rise the negative health and social consequences. ${ }^{6,7}$ Oral health status is often determined by the amount deposited on the surfaces of teeth and poor oral hygiene introduced as a predisposing factor to periodontal diseases and in contrast, healthy oral behaviours reduce the amount of deposits particularly plaque on the surfaces of teeth. ${ }^{6-8}$ With developing country like India, dental hygiene is poor with inadequate and improper brushing of teeth, no washing of mouth after intake of sweets, increased consumption of refined sugar and sweetened foods. Very extensive and 
comprehensive National Health Survey conducted in 2004 throughout India has shown dental caries in 51.9\% in 5 year-old children, $53.8 \%$ in 12 year-old children. ${ }^{3}$ Oral hygiene should be educated and practiced at early age as it is one of the determinants of the health state later in one's life. Considering the fact that there is the rise in the number of dental problems in school going children. Hence, the present study was undertaken to find out the oral hygienic practices among school going children and assess their oral health status.

\section{METHODS}

A cross-sectional study was conducted to assess the oral health status and hygienic practices among school children of medical area Jabalpur. Institutional ethical clearance was obtained prior to the study. Two schools around medical area were purposely selected. An informed consent for the participation of school children were obtained from the head of the school. Children fulfilling the following criteria: age between 10-15 years, so that they can easily understand and answer the questionnaire were included in study. Subjects with mixed dentition and those with acute infections of the oral cavity were excluded from the study. The purpose of the survey was informed and explained to the participants and those who voluntarily agreed to participate in the survey were asked the questionnaire and also the oral health examination was carried out.

Out of 450 children between age 10-15 yrs in both schools, 150 children fulfilling the above mentioned criteria 75 from each school were picked up by simple random sampling method so our sample size was of 150 and Study was carried in year 2014 in 6 month duration from $1^{\text {st }}$ July to $31^{\text {st }}$ December 2014 and total ten visits five for each school were paid for oral health survey, data collection and compilation.

Information was also collected through interviews with the children. A specially designed proforma on oral hygiene practices including regularity of cleaning the teeth, aids and agents used for this purpose and also frequency of brushing. The second part consisted of clinical examination for dental caries and treatment needs as described by WHO (1997) for oral health surveys. ${ }^{5}$ Caries was examined under natural day light using mouth mirrors and CPI probes.

\section{Statistical analysis}

All the analysis was done using SPSS 14 version. A pvalue of $<0.05$ was considered statistically significant. Chi-square test was used to compare the proportions between the groups.

\section{RESULTS}

$54.7 \%$ (82 students) were male and $45.3 \%$ (68 students) were female. Majority of students in our study were of lower $51.7 \%$ followed by lower middle class $32.7 \%$ and only $8 \%$ were from middle class.

Table 1: Oral hygienic practices among school going children.

\begin{tabular}{|c|c|c|}
\hline Frequency of brushing & Frequency & Percentage \\
\hline Morning & 115 & 76.6 \\
\hline Morning +evening & 34 & 22.7 \\
\hline After every meal & 1 & 0.7 \\
\hline \multicolumn{3}{|l|}{ Technique of brushing } \\
\hline Only horizontal & 117 & 78.0 \\
\hline $\begin{array}{l}\text { Correct (both } \\
\text { horizontally and } \\
\text { vertically) }\end{array}$ & 33 & 22.0 \\
\hline \multicolumn{3}{|c|}{ Habit of mouth rinsing or Gargling after meal } \\
\hline No & 65 & 43.3 \\
\hline Occasionally & 37 & 24.7 \\
\hline Regularly & 48 & 32.0 \\
\hline \multicolumn{3}{|c|}{ Malpractices among children } \\
\hline Chalk & 18 & 12.0 \\
\hline Soil & 1 & 0.7 \\
\hline Formite & 3 & 2.0 \\
\hline Tooth picking & 1 & .7 \\
\hline Chewing gum & 2 & 1.3 \\
\hline \multicolumn{3}{|c|}{ Change of brush with correct frequency } \\
\hline Yes & 56 & 37.3 \\
\hline No & 94 & 62.7 \\
\hline \multicolumn{3}{|c|}{ Habit of sweet milk at night } \\
\hline $\begin{array}{l}\text { Sweet milk at night not } \\
\text { followed by bush }\end{array}$ & 81 & 54.0 \\
\hline $\begin{array}{l}\text { Sweet milk at night } \\
\text { followed by brush }\end{array}$ & 15 & 10.0 \\
\hline $\begin{array}{l}\text { Don't consume milk } \\
\text { before sleep }\end{array}$ & 24 & 16.0 \\
\hline $\begin{array}{l}\text { Occasionally consume } \\
\text { irregular brushing status }\end{array}$ & 30 & 30.0 \\
\hline \multicolumn{3}{|l|}{ Brushing matter } \\
\hline Tooth paste+ brush & 130 & 86.7 \\
\hline Tooth powder+ brush & 8 & 5.33 \\
\hline Tooth paste+ finger & 0 & 0 \\
\hline Tooth powder+ finger & 1 & 0.7 \\
\hline $\begin{array}{l}\text { Others (coal, ash neem } \\
\text { twang) }\end{array}$ & 11 & 7.3 \\
\hline $\begin{array}{l}\text { Both indigenous } \\
\text { material and toothpaste }\end{array}$ & 7 & 4.7 \\
\hline
\end{tabular}

Various questions regarding the oral hygienic practices and oral health were asked. Result showed that only $34 \%$ children do brushing both time morning and at night before going to bed. Only $37 \%$ children replace brush with correct frequency. Only $22 \%$ of children use correct brushing technique. Most common malpractice among children was eating chalk $12 \%$. Regarding practice of milk intake at night followed by bushing was only $10 \%$ while $54 \%$ do not brush after taking milk at night. 
Table 2: Oral health problems among school going children.

\begin{tabular}{|lll|}
\hline Oral health problems & Frequency & Percentage \\
\hline Dental caries & 82 & 54.7 \\
\hline Cavity & 79 & 52.7 \\
\hline Staining & 33 & 21.9 \\
\hline Abscess formation & 5 & 3.3 \\
\hline Mouth ulcers- & 19 & 12.6 \\
\hline Bad breath & 21 & 13.9 \\
\hline Gingivitis & 20 & 13.2 \\
\hline Sensitivity & 35 & 23.2 \\
\hline Pain while chewing & 21 & 13.9 \\
\hline Malocculsion & 26 & 17.2 \\
\hline Tonsillitis & 30 & 19.9 \\
\hline Reason for which dental clinic visit were carried out \\
\hline Braces & 3 & 2.0 \\
\hline Crown filling & 2 & 1.3 \\
\hline Dental pain & 21 & 13.9 \\
\hline
\end{tabular}

A greater percentage of the students $86.7 \%$ practiced brushing with tooth brush and tooth paste and few used finger \& tooth powder $0.7 \%$. $11 \%$ students use indigenous material like neem twang, coal, and $4.7 \%$ students use both indigenous material as well as toothpaste. Only 32\% answered that they always do regular gargling after meal while $24.7 \%$ children rinse sometimes and majority of them $43 \%$ never rinse. Regarding oral health status of school children dental caries $54.7 \%$ followed by dental cavities $52.7 \%$ were most common problem found. Other common problems found were tooth sensitivity $23.2 \%$ and dental pain while chewing $13.9 \%$. $17.2 \%$ students reported that they would under gone dental clinic visit and most common reason for dental clinic visit was dental pain $13.9 \%$ and $2 \%$ students' undergone frequent dental visits for braces. $82.8 \%$ stated that they had never visited a dentist (Table 2 ). When association of dental caries and oral hygienic practices was studied it was found significantly associated with frequency of brushing ( $p$ value 0.003 ) and habit of brushing at night after consumption of sweet milk ( $p$ value 0.01). Also habit of rinsing mouth or gargling was found to be significantly associated with dental caries ( $\mathrm{p}$ value 0.004) (Table 3).

\section{DISCUSSION}

This cross-sectional study was conducted to determine the association between oral hygienic practices and oral health status. Frequency of morning brushing was found $76 \%$ which is higher than study conducted in Nepal by Barat $\mathrm{P}$ et al reported it being $60 \%{ }^{9}$

In terms of brushing, only $22 \%$ of the participants reported correct practice, which is similar to the studies conducted across the globe. Mehta et al showed only $11 \%$ of the participants practiced the correct method of brushing. ${ }^{10}$ Studies have reported that the concept of correct method of brushing develops over the years in an individual.

Table 3: Association of dental caries with hygienic practices.

\begin{tabular}{|c|c|c|c|}
\hline \multirow{2}{*}{$\begin{array}{l}\text { Oral hygienic } \\
\text { habits }\end{array}$} & \multicolumn{2}{|l|}{ Dental caries } & \multirow{2}{*}{ P value } \\
\hline & Not Present & Present & \\
\hline $\begin{array}{l}\text { Frequency of } \\
\text { brushing } \\
\text { morning }\end{array}$ & $60(52.2 \%)$ & $55(47.8 \%)$ & \multirow{3}{*}{$0.003 *$} \\
\hline $\begin{array}{l}\text { Morning } \\
\text { +evening }\end{array}$ & $7(20.6 \%)$ & $27(79.4 \%)$ & \\
\hline $\begin{array}{l}\text { After every } \\
\text { meal }\end{array}$ & $1(100 \%)$ & 0 & \\
\hline \multicolumn{4}{|c|}{ Technique of brushing } \\
\hline $\begin{array}{l}\text { Only } \\
\text { horizontal }\end{array}$ & $58(49.6 \%)$ & $59(50.4 \%)$ & \multirow[b]{2}{*}{0.05} \\
\hline $\begin{array}{l}\text { Correct (both } \\
\text { horizontally } \\
\text { and vertically) }\end{array}$ & $10(30.3 \%)$ & $23(69.7 \%)$ & \\
\hline \multicolumn{4}{|c|}{ Habit of mouth rinsing or gargling after meal } \\
\hline no & $37(56.9 \%)$ & $28(43.1 \%)$ & \multirow{3}{*}{$0.04 *$} \\
\hline occasionally & $13(35.1 \%)$ & $24(64.9 \%)$ & \\
\hline regularly & $18(37.5 \%)$ & $30(62.5 \%)$ & \\
\hline \multicolumn{4}{|c|}{ Habit of sweet milk at night } \\
\hline $\begin{array}{l}\text { Sweet milk at } \\
\text { night not } \\
\text { followed by } \\
\text { bush }\end{array}$ & $33(40.7 \%)$ & $48(59.3 \%)$ & \multirow{3}{*}{$0.01 *$} \\
\hline $\begin{array}{l}\text { Sweet milk at } \\
\text { night followed } \\
\text { by brush }\end{array}$ & $6(40.0 \%)$ & $9(60.0 \%)$ & \\
\hline $\begin{array}{l}\text { Don't consume } \\
\text { milk before } \\
\text { sleep }\end{array}$ & $17(70.8 \%)$ & $7(29.2 \%)$ & \\
\hline $\begin{array}{l}\text { Occasionally } \\
\text { consume }\end{array}$ & $12(33.3)$ & $18(66.7 \%)$ & \\
\hline \multicolumn{4}{|c|}{ Brushing matter } \\
\hline $\begin{array}{l}\text { Tooth paste+ } \\
\text { brush }\end{array}$ & $66(46.5 \%)$ & $76(53.5 \%)$ & \multirow{4}{*}{0.235} \\
\hline $\begin{array}{l}\text { Tooth powder+ } \\
\text { brush }\end{array}$ & $2(25.0 \%)$ & $6(75.0 \%)$ & \\
\hline $\begin{array}{l}\text { Tooth paste+ } \\
\text { finger }\end{array}$ & & 0 & \\
\hline $\begin{array}{l}\text { Tooth powder+ } \\
\text { finger }\end{array}$ & & $1(100 \%)$ & \\
\hline
\end{tabular}

The observed rate is lower than with the studies conducted by Sara Dakhili et al who reported it being $90 \% .^{11}$ These differences in observation could be due to the research methodological differences in the studies and also the socio-cultural and demographic variations within and between countries.

According to our research more than $37 \%$ change the brush in correct frequency whereas a study conducted in 
Pakistan reported similar percentage. ${ }^{12}$ A Study conducted in India, showed higher percentage with regard to correct frequency of changing brush. ${ }^{13}$ This difference in practice may be a result of higher knowledge in oral hygiene. That means those who have adequate knowledge on the importance of brushing, practice the habit of changing their brush at the appropriate time. A greater percentage of the students $(86.7 \%)$ practiced brushing with tooth brush and tooth paste similarly observed by Suprabha BS, Rao A. ${ }^{14} 54.7 \%$ students had dental caries in our study, in a similar study by Amin et al found it $68.9 \%$ among school going children.

In our study oral hygienic practices like frequency of brushing, habit of gargling, and consumption of sweet milk at night was found significantly associated with dental carries similar observation were made by Amin and Al-Abad BM et al found that poor oral hygiene practices, lack of parental guidance and appropriate dental health knowledge with frequent exposure to cariogenic foods in addition to socio-demographics are the main risk factors for dental decay among the surveyed students. ${ }^{15}$ A study carried by Sullia Taluk found lower prevalence of dental carries among children brushing teeth twice and using tooth paste and brush. ${ }^{16}$ According to our study $82.8 \%$ had never visited a clinic for oral health problem while $54.7 \%$ students had dental caries in our study showed a large gap between oral problems and health seeking behavior regarding oral health problems.

\section{CONCLUSION}

Oral hygienic practices regarding importance of brushing, frequency of brushing, frequency of changing the brush, were poor needs educational motivation regarding duration of brushing, appropriate way to brush the teeth, and use of mouthwash. More over our study showed a large gap between oral problems and health seeking behavior regarding oral health problems hence comprehensive community-focused oral health care intervention that includes oral health education in elementary schools and homes to increase general oral health awareness is strongly recommended.

\section{ACKNOWLEDGEMENTS}

The authors offer their sincere thanks to school teachers of Digamber verni Gurukul School and government school for their cooperation and medical students Dr. Shrueshtha and Dr. Jyoti, for helping in survey without which this study would not have been possible.

Funding: No funding sources

Conflict of interest: None declared

Ethical approval: The study was approved by the Institutional Ethics Committee

\section{REFERENCES}

1. Rimondini L, Zolfanelli, Bernardi B, Bez C. Self preventive oral behaviour in an Italian university student population. J Clin Periodontology. 2001;28:207-11.

2. Hedman E, Ringberg K, Gabre P. Oral health education for schoolchildren: a qualitative study of dental care professionals' view of knowledge and learning. International journal of dental hygiene. 2009;7:204-11.

3. National Oral Health Survey and Fluoride Mapping. An Epidemiological Study of Oral Health Problems and Estimation of Fluoride Levels in Drinking Water. Dental Council of India: New Delhi. 2004;32:67-78.

4. Friel S, Hope A, Kelleher C, Comer S, Sadlier D. Impact evaluation of an oral health intervention amongst primary school children in Ireland. Health promotion international. 2002;17:119-26.

5. Mathur A, Gupta, T. Oral health attitude knowledge behaviour and consent towards dental treatment among school children. Journal of orofacial research. 2011;1:6-10.

6. Loesche WJ. Association of the oral flora with important medical diseases: Current opinion in periodontology. International Journal of Health Sciences. 2014;2:6.

7. Ojahanon PI, Akionbare O, Umoh AO. The oral hygiene status of institution dwelling orphans in Benin City, Nigeria. Nigerian journal of clinical practice 2013;16:41-4.

8. Gajewski BJ, Coffland V, Boyle D, Bott M, Price LR, Leopold J, etal. Assessing content validity through correlation and relevance tools. Methodology. 2012;8:81-96.

9. Baral P, Bhattarai C, Poudel PP, Banstola D, Roy S, Hada S. A Study on Oral Hygiene Practice among School Children of Pokhara Municipality. Journal of CMC. 2009;2:37-8.

10. Amrita M, Siddhant P, Samved P, Suchetan P. The oral hygiene habits and general oral awareness in public schools in Mumbai. International Journal of Laser Dentistry. 2013;3:60-7.

11. Dakhili S, Alsuwaidi NO, Saeed S, Murad SB, Mohammad D, J Muttappallymyalil J. Oral Hygiene: Association between knowledge and Practice among school going children in Ajman, United Arab Emirates. 2014;2:3.

12. Khan A, Khan M, Khan AA. Oral Health Related Knowledge, Attitude and Practices among PatientsA Study. Pakistan Oral \& Dental Journal. 2010;30:186-91.

13. Gupta T, Sequeira P, Acharya S. Oral health knowledge, attitude and practices of a 15-year-old adolescent population in Southern India and their social determinants. Oral Health Prev Dent. 2012;10:345-54.

14. Baranya SS, Arathi R, Ramya S, Sanskriti K. Utility of knowledge, attitude, and practice survey, and 
prevalence of dental caries among 11 to 13 year-old children in an urban community in India. Global Health Action. 2013;6:750-5.

15. Amin TT, Al-Abad BM. Oral hygiene practices, dental knowledge, dietary habits and their relation to caries among male primary school children in $\mathrm{Al}$ Hassa, Saudi Arabia. Int J Dent Hyg. 2008;6:36170.

16. Praveena S, Thippeswamy HM, Nanditha K, Kalyana Chakravarthy P. Relationship of Oral
Hygiene Practices and Dental Caries among School Children of Sulliataluk, Karnataka. South India Global Journal of Medical research dentistry and Otolaryngology. 2013;13:2.

Cite this article as: Tomar SP, Kasar PK, Tiwari R. Study of oral hygienic practices and oral health status among school children in Jabalpur, Madhya Pradesh: a cross-sectional study. Int J Community Med Public Health 2016;3:403-7. 